\title{
BRIEF ASSESSMENT OF PHARMACIST-PATIENT COMMUNICATION EFFICIENCY IN ROMANIAN PHARMACIES
}

\author{
AURA RUSU ${ }^{1}$, CAMIL-EUGEN VARI ${ }^{2}$, GABRIEL HANCU $^{1 *}$, MARIA DORINA PASCA $^{3}$, \\ RALUCA BOTEZATU ${ }^{1}$, DRAGOS CUCORANU ${ }^{4}$, DANIELA LUCIA MUNTEAN ${ }^{5}$ \\ University of Medicine, Pharmacy, Sciences and Technology of Târgu Mureș, 38 Gh. Marinescu Street, RO-540139, Târgu \\ Mureș, Romania \\ ${ }^{I}$ Faculty of Pharmacy, Pharmaceutical Chemistry Department \\ ${ }^{2}$ Faculty of Pharmacy, Department of Pharmacology and Clinical Pharmacy \\ ${ }^{3}$ Faculty of Medicine, Department of Ethics and Social Science \\ ${ }^{4}$ Faculty of Medicine \\ ${ }^{5}$ Faculty of Pharmacy, Department of Analytical Chemistry and Drug Analysis
}

*corresponding author: gabriel.hancu@umftgm.ro

Manuscript received: January 2018

\begin{abstract}
The pharmacist is the final specialist in the triad physician-pharmacist-patient, but has maybe the greatest responsibility in the success of the treatment. This research is aimed mainly to evaluate the efficiency of the communication level between the pharmacist and the patients in Romanian pharmacies. The questionnaire method was applied in the period between April 2016 and May 2016, 689 patients were randomly selected at the exit of pharmacies. The results of the survey indicated that the communication with the patient need to be optimized through multi-question inquiry and drug-related advice: how to administer the medicine, doses, common side effects and treatment-appropriate diets. Also, a discontinuity regarding the professional relationship with the patient was also observed. Generally, the estimated level of communication efficacy with the patient reaches approximately $64 \%$. The challenge of the future for the pharmacists should be a pharmaceutical care practice in accordance with patient individual needs based on a more efficient communication.
\end{abstract}

\section{Rezumat}

Farmacistul este specialistul final din triada medic-farmacist-pacient, cu responsabilitate ridicată în succesul tratamentului. Acest studiu are ca scop evaluarea eficienței comunicării dintre farmacist și pacient în farmaciile din România. Metoda chestionarului a fost aplicată în perioada aprilie - mai 2016, pe un număr de 689 de pacienți selectați aleator la ieșirea din farmacie. Analiza obținută a indicat faptul că este necesară optimizarea gradului de comunicare cu pacientul în ceea ce privește investigarea prin mai multe întrebări și consilierea legată de medicament: modul de administrare, doze, reacții adverse comune și diete adecvate tratamentului. A fost observată și o discontinuitate a relației profesionale cu pacientul. La modul general, nivelul estimat al eficienței comunicării farmacistului cu pacientul a fost de aproximativ 64\%. Provocarea farmacistului modern trebuie să fie exercitarea profesiei în acord cu nevoile individuale ale pacientului, bazată pe o comunicare mai eficientă cu acesta.

Keywords: communication, pharmacy, pharmacist, patient

\section{Introduction}

In the triad physician-pharmacist-patient, the pharmacist working in the community pharmacy is the final specialist responsible for the patient's medication and treatment to be administered. The modern pharmacist is a "pharmaceutical care" practitioner who assumes responsibility for the patient's needs in terms of drug and therapeutic success [12]. Pharmaceutical services have a current trend in surpassing the traditional role in dispensing the medicines, as is the case of patients with hypertension or diabetes $[2,17,26]$. Upgrading the role of the modern pharmacies is part of a global trend with new pharmaceutical services under a wide range of "cognitive pharmaceutical services". There is a desire and a trend for the pharmacist to become more involved in patient care, both in hospital pharmacies and community pharmacies. This presents an important challenge to the pharmaceutical profession which is attested as providing optimal patient care [13, 16, 19]. However, several studies have revealed gaps in pharmacist-patient communication, in particular, due to the fact that pharmacists have not switched from a practice focused on drugs to a practice focused on the patient, customized to their individual needs $[6,9,21$, $23,28]$. The major objective of this study is to evaluate the efficiency of pharmacist-patient communication from the patient's perspective. Other objectives derived from the major objective concern a quantification of the transmission of the most important information regarding the medication is transmitted to the patients and to evaluate the pharmacist's attitude in carrying 
FARMACIA, 2018, Vol. 66, 6

out the professional act and non-verbal aspects of communication in the patient counselling.

\section{Materials and Methods}

The assessment method was the questionnaire. Patient selection was randomly made, while they were leaving the pharmacy, with the patient's consent; the public space (outside the pharmacy) was selected to avoid influencing the patient by the presence of the pharmacist. The sample created was non-probabilistic, without any required criteria. A total of 689 questionnaires was centralized and analysed. The period of questionnaire collection was April - May, 2016. Data privacy was assured and ethical considerations of any kind have not been infringed. The statistics were performed by the GraphPad InStat 3.1 software [31]. The questionnaire consisted of two main parts: a part that contained identification data (date, time, pharmacy, city, county, name and first name of the patient - optional, gender, and age) and the other part containing a series of 20 questions aimed to evaluate the effectiveness of pharmacist-patient communication. The questions were in accordance with the principles of pharmaceutical practice regulated in the Romanian Pharmaceutical Good Practice Rules [7, 32].

\section{Results and Discussion}

The analysed questionnaires were completed in April May 2016. There was no specific time frame for approaching the patients when leaving the pharmacy, the questionnaires being completed by the patients throughout the day ( $8 \mathrm{AM}$ to $8 \mathrm{PM}$ ), most of the questionnaires $(51.52 \%)$ being completed from 12 $\mathrm{PM}$ to $4 \mathrm{PM}$. Other questionnaires were completed from $8 \mathrm{AM}$ to $12 \mathrm{PM}(22.64 \%)$, from $4 \mathrm{PM}$ to 8 PM $(20.75 \%)$ and at an unspecified time (5.08\%). The questionnaires were collected in 11 Romanian counties. Pharmacies have not been selected prior to the questionnaire. The locations of pharmacies whose patients were approached by volunteers were predominantly located in an urban area $(94.05 \%)$, the rural area being less represented (5.95\%). The patients included in the study attended chain pharmacies $(358 ; 51.96 \%)$ and local pharmacies
(351; 48.04\%), the share of the two being almost equal. The name and surname have been recorded optionally, leaving the possibility of anonymity available, ensuring there was no pressure on the patient and that no answers were biased. Patients who completed the questionnaires were predominantly women $(61.83 \%)$. The large number of female respondents can also be attributed to the fact that women are generally more concerned with health care and beauty than men $[1,15,20,29]$. The age of questionnaire respondents was between 18 and 88 years, with an average of 42 years old, with the largest proportion of patients aged between 20 and 29. The percentages of patient age categories who participated in our survey decreased with the age: 20 - 29 years $(25.25 \%), 30-39$ years $(15.97 \%), 40$ - 49 years $(17.71 \%), 50$ - 59 years $(12.77 \%), 60$ - 69 years (11.32\%), $70-79$ years $(4.06 \%), 80-88$ years $(1.89 \%)$ categories; under 20 years $(2.32 \%)$ and unreported age $(8.71 \%)$. The specific questions were simple in order to evaluate the effectiveness of communication with the pharmacist and correlated with Romanian Rules of Pharmaceutical Good Practice [32]. The question no. 1 aimed to find out why the patient visited the pharmacy (several answers were accepted for this question). As expected, the highest percentage was the number of patients who had a medical prescription $(44.56 \%)$. However, a proportion of $38.61 \%$ of patients went to the pharmacy to purchase medication on their own (self-medication), much higher than in other European countries (e.g. Austria 8\%, Spain and United Kingdom 9\%, Germany 11\%) [3]. Thus, the percentage of patients considering the purchase of medicines (with or without a prescription) was $83.17 \%$. Other answers totalized $23.5 \%$ (to acquire other health products and medical devices, to inform their selves or other reasons). The question no. 2 addressed several aspects of the pharmacist's approach, such as visual contact with the patient when entering the pharmacy, greeting the patient, if the pharmacist smiled and had a proactive and empathic attitude. Other aspects were related to the pharmacist's appearance: wearing the white coat and if the white coat was clean, wearing the badge and if the patient remembered the badge position information (Table I).

Table I

The results of question no. 2

\begin{tabular}{|l|c|c|c|}
\hline \multicolumn{1}{|c|}{ Question } & Yes (\%) & No (\%) & Incomplete/*I don't know (\%) \\
\hline a) The pharmacist noticed when you entered in pharmacy? & 90.57 & 8.56 & 0.87 \\
\hline b) The pharmacist welcomed when you entered the pharmacy? & 89.26 & 10.3 & 0.44 \\
\hline c) The pharmacist smiled when you entered the pharmacy? & 69.09 & 30.33 & 0.58 \\
\hline d) Was the pharmacist wearing a white coat? & 99.85 & 0 & 0.15 \\
\hline e) Was the white coat clean? & 98.55 & 0.44 & 1.02 \\
\hline f) The pharmacists were wearing a badge? & 80.26 & 1.6 & $* 18.14$ \\
\hline g) Did you notice the name on the badge? & 22.35 & 76.63 & 1.02 \\
\hline h) Did you notice the function of the specialist stated on the badge? & 44.27 & 54.72 & 1.02 \\
\hline i) Did the pharmacist have a proactive attitude? & 86.36 & 12.05 & 1.6 \\
\hline j) Did the pharmacist have an empathic attitude? & 90.42 & 8.42 & 1.16 \\
\hline
\end{tabular}


An important step in counselling the patient is to collect data about the state of health (question no. 3: How many questions did you receive from Pharmacist/ Pharmacy Assistant?). The patients responded that 1 - 2 questions (29.03\%) were addressed, 2 - 4 questions were addressed (29.61\%), and also 5 - 6 questions (15.67\%) were addressed. The lowest percentage belonged to patients who reported more than 6 questions from the pharmacist $(6.82 \%)$. Unfortunately, there were situations where no questions were asked by the pharmacist (18.87\%), this being an important step in patient counselling, no matter what type of product they desired from the pharmacy. However, the results were not very different from

the average of questions asked by the pharmacist in a recent study in Canada, where pharmacists asked an average of $8 \pm 4$ close-ended questions and $1 \pm 1$ open-ended question per encounter [10]. Pharmacists' communication could be optimised at the start of the counselling by asking open-ended questions in order to identify health problems and concerns of the patients [5]. The questions are very important in pharmaceutical counselling taking into consideration the information shared with the patients regarding their health needs and concerns. The share of answers to questions strictly related to medication, in the case of patients considering purchasing medication (with or without a prescription), is included in Table II.

Table II

The results of questions 4-9

\begin{tabular}{|c|l|c|c|}
\hline \multicolumn{1}{|c|}{ Questions } & \multicolumn{2}{c|}{ Answers (\%) } \\
\cline { 2 - 4 } & \multicolumn{1}{|c|}{$\begin{array}{c}\text { Affirmative } \\
\text { No information }\end{array}$} \\
\hline 4. & $\begin{array}{l}\text { Have you been informed about the name (other trade names, synonyms) of the } \\
\text { medicine and its concentration? }\end{array}$ & 76.96 & 23.04 \\
\hline 5. & Have you been informed about the purpose of the treatment and the effects of the drug? & 84.81 & 15.19 \\
\hline 6. & $\begin{array}{l}\text { Have you been informed about the route of administration of the medicine (oral, local, } \\
\text { nasal, etc.)? }\end{array}$ & 94.06 & 5.94 \\
\hline 7. & $\begin{array}{l}\text { Have you been informed about how to take your medicine (example with 1 glass of } \\
\text { water)? }\end{array}$ & 74.86 & 25.14 \\
\hline 8. & $\begin{array}{l}\text { Have you been informed about the administration of the medicine regarding the main } \\
\text { meals? (Before/after/during the meal)? }\end{array}$ & 84.29 & 15.71 \\
\hline 9. & Have you been informed about the one time and 24 hour doses of the medicine? & 74.69 & 25.31 \\
\hline
\end{tabular}

It can be noted that approximately a quarter of patients who entered the pharmacy to obtain the medication were not informed about important drug-related issues (doses, administration, name, and concentration). The highest percentage related to the lack of information about the medication was the dose aspect for one usage and for 24-hours (25.31\%, question no. 9), almost equal to drug administration issues $(25.14 \%$, question no. 7) and the drug name/synonyms and concentration (23.04\%, question no. 4 ). The lack of information about the doses could be strongly related to the therapeutically failure and the exacerbation of certain adverse effects, and even with overdosing. In a short previous study, we highlighted the phenomenon of non-adherence to treatment as a high concern among chronic patients; the information about the prescription was obtained mainly from the general practitioner or specialist physician [27]. On the other end, the lowest percentage was represented by information on the route of administration (5.94\%, question no. 6). The route of administration is an essential aspect for the patient, and this can be the reason for the high percentage regarding this critical information. Other studies have also highlighted the lack of communication or insufficient communication of drug-related information [23, 25]. The next questions have verified whether the patient was informed about the time between administrations (question no. 10) and the duration of drug administration (question no. 11). Of the total number of patients who had a prescription or used self-medication, $13.62 \%$ did not receive information about the time between two administrations and a higher percentage $(21.64 \%)$ did not receive information about the drug administration period or the duration of treatment. Considering that many drugs, including OTCs, have a specific administration period for the therapeutic success, patients who have not received such information are more likely to fail in their treatment. Answers to questions no. 12 - 14 provided us data on the patients' knowledge of drug precautions and contraindications, predictable adverse effects as well as about adequate nutrition and a healthy lifestyle according to the drug regimen (Figure 1). The obtained data showed that the pharmacist did not give information in over 50\% of cases regarding the precautions and contraindications of the drugs and in over $60 \%$ of patients about the adverse effects of the drug. It has also been reported in other studies that pharmacists avoid giving the patient a warning about the drug's side effects, believing that they may become reductant and give up on the medication, although many patients become more alert when they receive this information and grant more importance to medication [25]. Some studies even noted the patient's desire to get more date about the adverse effects of the drug $[11,22]$. In the case of question no. 14 , it was noticed that $75 \%$ of patients did not receive information about adequate 
FARMACIA, 2018, Vol. 66, 6

nutrition for the medication regimen and about adopting a healthy lifestyle. The reasons for this lack of information can be numerous: lack of time, lack of a pattern of patient counselling on important issues, ignoring that these issues are important to patients, technical errors, etc.

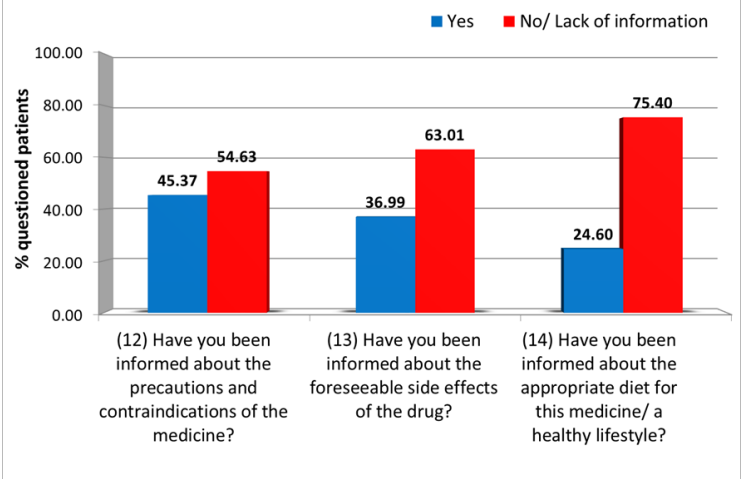

Figure 1.

The results of questions $12-14$

The way medication is stored is an important aspect in ensuring the success of the patient's treatment and is the responsibility of the patient (question no. 15: Have you been informed about the proper storage of medicines and compliance with the validity period?). However, the patient should be informed at the pharmacy about the temperature at which medication should be stored, other special conditions, and especially that it should not be left in the reach of children if it's the case. The expiration date is very important, especially for products that have a short validity term after opening (eye drops, nose drops, etc.). Over $70 \%$ of the patients surveyed were not advised on this matter. The minimum hygiene rules that should be respected when administering pharmaceutical products are also very important. Regarding these aspects, the percentage of patients who did not receive minimal information was about $75 \%$ (question no. 16: Have you been informed about the minimum hygiene rules that should be respected while?). The attitude of the pharmacist during counselling can greatly influence treatment therapeutic success and adherence to treatment. Thus, the answers were given by the patients to question no. 17 (Did the pharmacist give you confidence in the treatment to follow?) showed that they have been given confidence in the medication they had prescribed or asked for on their own in a very large percentage, over $95 \%$. Even though some of the drug-related counselling has been incomplete, the patient's perception of pharmaceutical services was positive, overall trusting the treatment to be followed, a situation also reported by a recent study in Japan [30]. The closing phase of the conversation is the stage in which a long-lasting professional pharmacistpatient relationship can be created and therefore a polite, respectful behaviour from the pharmacist is required. In addition, the patient should be convinced to return to the pharmacy where they have quality pharmaceutical services at their disposal $[4,7]$. From the patients' answers, it appears that in the analysed sample, although most patients were greeted on their leave and were satisfied with the services (because they came to the pharmacy, had patience and trust in a pharmacist, etc.) only half of them were advised to come back for additional monitoring (questions 18 - 20) (Figure 2). The effectiveness of pharmacistpatient communication is hard to quantify due to the limitations imposed by the applied methods [25].

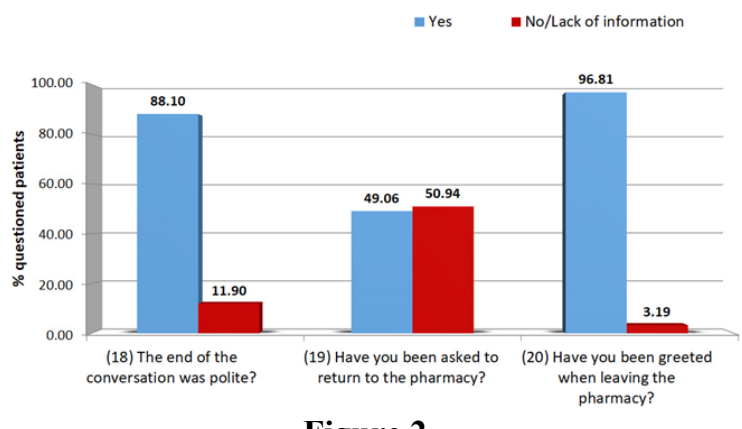

Figure 2.

The results of questions $18-20$

Not all questionnaires were fully completed (examples of omissions: age, time of completion, blank answers, etc.) [24]. The level of understanding of the questions in the questionnaire may vary from patient to patient. Taking into account these limitations, the effectiveness of the pharmacist's communication with the patient (Figure 3) was evaluated at $63.85 \%$ based on the results of the questionnaire. The percentage can be considered low and results quite alarming, pharmaceutical counselling being an important step in the modern therapeutically process and in the success of patient treatment. In Romanian pharmacies, under the supervision of the pharmacist, according to the legislation, pharmacy assistants can also release a certain type of medications with medical prescriptions. Some gaps in patient counselling can also be attributed to the technical errors of the physicians who issued the prescription.

The pharmaceutical faculties need to extend and adapt their curricula in terms of acquiring more communication skills in the interest of future pharmacists. Thereby, the pharmacists require more training in developing communication skills with the patient, a need already reported by previously published studies in other countries $[14,18,23]$. 


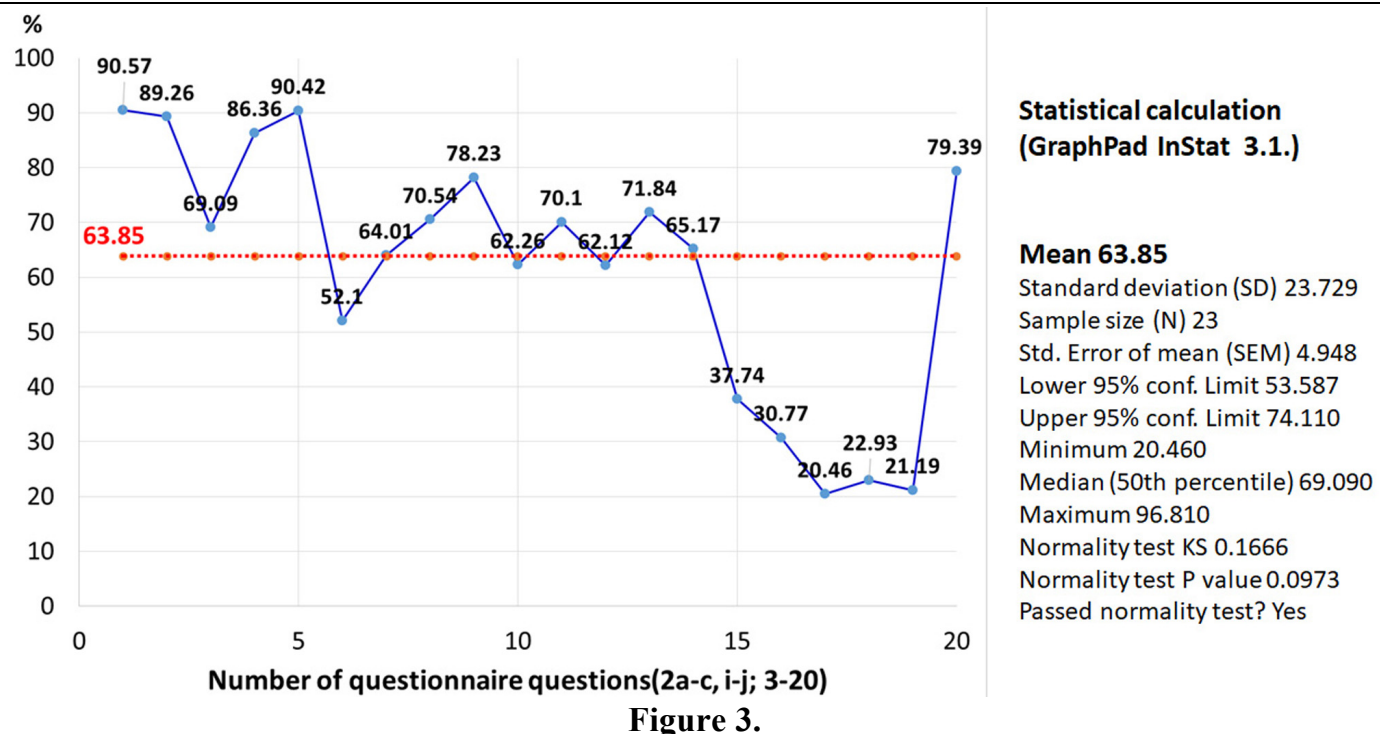

The estimation of pharmacist's communication with the patient

\section{Conclusions}

In the community pharmacy, the pharmacist is the last specialist in charge of interacting with the patient. The current study has been shown that the communication of pharmacy specialists with the patient needs to be improved regarding the interaction with the patient through more questions, sufficient counselling about drug administration methods, information regarding dosing, common adverse reactions, and the proper nutritional requirements in accordance with the treatment. Also, very important is to build a professional relationship with the patient. In order to assure the therapeutical success and in accordance with the rules of good pharmaceutical practice, counselling is a professional responsibility for pharmacists. The estimated level of efficacy in communicating with the patient in Romanian pharmacies could be easily improved by a higher degree of implication and responsibilities of the pharmaceutical health care team for the patients' needs regarding medicines. In a competitive market, the challenge of the future pharmacist should be a pharmaceutical care practice in accordance with patients' individual needs based on more efficient communication.

\section{Acknowledgement}

Special thanks to students from the $2^{\text {nd }}$ year (2015 2016), Faculty of Pharmacy, Romanian section, University of Medicine, Pharmacy, Sciences and Technology of Târgu Mureș, Romania, who were the volunteers involved in collecting data.

\section{Conflict of interest statement}

The authors declare no conflicts of interest.

\section{References}

1. Angeles-Chimal P, Medina-Flores ML, MolinaRodríguez JF, Self-medication in a urban population of Cuernavaca, Morelos. Salud Publica Mex., 1992; 34(5): 554-561.

2. Babinec PM, Rock MJ, Lorenzetti DL, Johnson JA, Do researchers use pharmacists' communication as an outcome measure? A scoping review of pharmacist involvement in diabetes care. Int $J$ PharmPract., 2010; 18: 183-193.

3. Bennadi D, Self-medication: A current challenge. $J$ Basic Clin Pharm., 2013; 5(1): 19-23.

4. Boboia A, Oros GC, Polinicencu C, Mirel S, Researches concerning the profitability of the community pharmacy within the context of world economic and financial crisis. Farmacia, 2014; 62(5): 1025-1036.

5. Chevalier BAM, Watson BM, Barras MA, Cottrell $\mathrm{WN}$, Investigating strategies used by hospital pharmacists to effectively communicate with patients during medication counselling. Health Expect., 2017; 20(5): 1121-1132.

6. Chong WW, Aslani P, Chen TF, Pharmacist-patient communication on use of antidepressants: a simulated patient study in community pharmacy. Res Social Adm Pharm., 2014; 10(2): 419-437.

7. Crişan $\mathrm{O}$, Good pharmacy practice in the context of crossborder healthcare. Farmacia, 2017; 65(2): 310316.

8. Crişan $\mathrm{O}$, Iacob S, Codes of deontology for health professionals - a comparative analysis. Farmacia, 2016; 64(4): 625-632.

9. de Oliveira DR, Shoemaker SJ, Achieving patient centeredness in pharmacy practice: openness and the pharmacist's natural attitude. $J$ Am Pharm Assoc., 2006; 46: 56-66.

10. Deschamps M, Dyck A, Taylor J, What are we saying? Content and organization of patient counseling by community pharmacists. Can Pharm J., 2003; 136: $42-47$.

11. Dickinson D, Raynor DK, Ask the patients-they may want to know more than you think. BMJ., 2003; 327: 861-864. 
12. Duggan $C$, Primary and Secondary Care Pharmacy, Pharmacy practice, Taylor \& Francis Group, New York, 2005; 43-47.

13. Epstein RM, The science of patient-centered care. $J$ Fam Pract., 2000; 49: 805-807.

14. Greenhill N, Anderson C, Avery A, Pilnick A, Analysis of pharmacist-patient communication using the CalgaryCambridge guide. Patient Educ Couns., 2011; 83(3): 423-431.

15. Honigman R, Castle DJ, Aging and cosmetic enhancement. Clin Interv Aging, 2006; 1(2): 115-119.

16. Isasi $F$, Krofah E, The Expanding Role of Pharmacists in a Transformed Health Care System, NGA Paper, Washington, D.C., 2015; 1-14. (www.nga.org/files/live/ sites/NGA/files/pdf/2015/1501TheExpandingRoleOf Pharmacists.pdf)

17. Johnson CL, Nicholas A, Divine H, Perrier DG, Blumenschein K, Steinke DT, Outcomes from DiabetesCARE: a pharmacist-provided diabetes management service. J Am Pharm Assoc., 2008; 48: 722-730.

18. Kerr A, Strawbridge J, Kelleher C, Mertens F, Pype P, Deveugele M, Pawlikowska T, How can pharmacists develop patient-pharmacist communication skills? A realist review protocol. Syst Rev., 2017; 6(14): 1-7.

19. Macgregor P, Change: The Future of Pharmacy. Can J Hosp Pharm., 2014; 67(6): 464.

20. Manteuffel M, Williams S, Chen W, Verbrugge RR, Pittman DG, Steinkellner A, Influence of patient sex and gender on medication use, adherence, and prescribing alignment with guidelines. $J$ Womens Health (Larchmt). 2014; 23(2): 112-119.

21. Murad MS, Chatterley T, Guirguis LM, A metanarrative review of recorded patient-pharmacist interactions: exploring biomedical or patient-centered communication?. Res Social Adm Pharm., 2014; 10(1): 1-20.

22. Nair K, Dolovich L, Cassels A, McCormack J, Levine M, Gray J, Mann K, Burns S, What patients want to know about their medications: Focus group study of patient and clinician perspectives. Can Fam Physician, 2002; 48: 104-110.

23. Olsson E, Ingman P, Ahmed B, Kälvemark Sporrong S, Pharmacist-patient communication in Swedish community pharmacies. Res Social Adm Pharm., 2014; 10(1): 149-155.

24. Paşca MD, Hancu G, Soare R, Budău M, Rusu A, Logistic and constructive attitude perception of pharmacist students towards medicine. Farmacia, 2015; 63(5): 720-725.

25. Puspitasari HP, Aslani P, Krass I., A review of counseling practices on prescription medicines in community pharmacies. Res Social Adm Pharm., 2009; 5(3): 197-210.

26. Robinson JD, Segal R, Lopez LM, Doty RE, Impact of a pharmaceutical care intervention on blood pressure control in a chain pharmacy practice. Ann Pharmacother., 2010; 44: 88-96.

27. Rusu A, Hancu G, Paşca MD, Aspects of adherence to treatment in community pharmacy. Therap Pharmac Clin Tox., 2010; XIV(3): 217-223.

28. Shah B, Chewning B, Conceptualizing and measuring pharmacist-patient communication: a review of published studies. Res Social Adm Pharm., 2006; 2(2): 153-185.

29. Spettigue W, Henderson KA, Eating Disorders and the Role of the Media. Can Child Adolesc Psychiatr Rev., 2004; 13(1): 16-19.

30. Takaki H, Abe T, Hagihara A, Perceptions of pharmacists and patients on information provision and their influence on patient satisfaction in Japanese community pharmacies. J Eval Clin Pract., 2015; 21(6): 1135-1141

31. ${ }^{* * *}$ GraphPad Instat 3.1 [software] available from http://graphpad-instat.software.informer.com/3.1

32. *** Ministry of Health, Order no. 75/2010 for the approval of good pharmacy practices rules. Official Journal of Romania, $1^{\text {st }}$ part, no. 91/2010, (available in Romanian). 